\title{
ESTABLISHMENT OF APICAL SHOOT MERISTEM CULTURE FOR in vitro CONSERVATION OF SUNFLOWER (Helianthus annuus L.) GENETIC RESOURCES
}

\author{
Dağüstü, N. ${ }^{*}$, Bayraktaroğlu, M. and Güden, B.
}

Uludağ University, Faculty of Agriculture, Department of Field Crops, 16050, Görükle, Bursa, Turkey

Received: November 15, 2011 Accepted: December 10, 2011

\section{SUMMARY}

A high regeneration capacity is important for in vitro conservation of genetic resources and transformation studies. The research was conducted at Uludağ University, Agricultural Faculty, Field Crops Department, and Plant Tissue Culture Laboratory in 2011. Ten genotypes (T0910817-1, T0910950-2, T0910791-3, T0910182-2, T0910792-1, T0912285-1, T0911033-2, T0910791-1, T0910791-4 and T0910930-2) were used as plant materials. The apical shoot meristems of sunflower genotypes (Helianthus annuus L.) were dissected from 4 day-old seedlings and transferred to $1 / 2 \mathrm{MS}$ medium allowing shoot and root development. The experiments were placed into growth chamber in $16 / 8$ hour light/dark photoperiod at $26 \pm 2{ }^{\circ} \mathrm{C}$ for two weeks. They were transplanted into vial containing a 1:1:2 peat-perlite-soil mixture $(\mathrm{v} / \mathrm{v})$ for acclimatization, covered with nylon bags and kept at $25 \pm 2^{\circ} \mathrm{C}$ in $16 \mathrm{~h} / 8 \mathrm{~h}$ (light/dark) in a growth chamber for 2 weeks. Young plantlets were transferred to unsterile soil and developed to maturity. They were self-pollinated in the natural conditions. The agronomic characters (plant height, head diameter, number of leaves, stem diameter, number of branches) of in vitro grown plants were measured before harvesting. The data was analyzed with Jump statistical programme in the completely randomized design with 3 replications, each replication consisted of one pot with 6 plants.

Out of 10 genotypes, seven showed a notable response to the in vitro establishment. The $67.33 \%$ of all cultured apical shoot meristems developed into vigorous plantlets with 3-6 leaves. The majority of the developed plantlets had vigorous root. Almost all of the plantlets grew healthy and produced fertile plants in green house conditions. The analysis of variance for all agronomic characters, except for the number of branches, resulted in significant differences among genotypes at 5\% level. The genotype with a relatively high regeneration capacity and agronomic performances was T0911033-2 followed by T0910950-2. Plant regeneration from apical shoot meristem of sunflower is

* Corresponding author: Phone: +90 224 2941518; Fax: +90 224 2941402;

e-mail:ndagustu@uludag.edu.tr 
practical and efficient when appropriate genotype and sterilization procedure are used.

Key words: sunflower, apical shoot meristem, fertile plant regeneration

\section{INTRODUCTION}

The sunflower (Helianthus annuus L.) is one of the most important oil seed crops, not only in Turkey, but also in the world. Increasing oil and nutritional content, agronomic performances, disease and insect resistance and oil quality by genetic manipulation are the main targets of present sunflower breeding programmes. In vitro conservation of sunflower genetic resources and genetic transformation are also becoming a complementary approach to the conventional conservation and breeding methods.

The first sunflower plantlet regeneration was reported by Sadhu in 1974. Since then many successful attempts have been done by various explants, such as immature embryo (Encheva et al., 2004), mature embryo (Ozyigit et al., 2007), meristem (Paterson, 1984), anther (Nurhidayah et al., 1996), hypocotyl (Greco et al., 1984), and cotyledon (Ceriani et al., 1992). Although plant regeneration via tissue culture have been achieved in earlier studies with many sunflower inbred and hybrid lines by applying either organogenesis (Ceriani et al., 1992) or somatic embryogenesis (Fiore et al., 1997; Paterson and Everett, 1985), sunflower is a recalcitrant plant in terms of transformation and regeneration (Power, 1987). The process of sunflower regeneration is affected by many factors, either alone or in combination. These include genotype (Dağüstü, 2002; Paterson, 1984; Power, 1987), composition of culture medium (Shin et al., 2000), the age of explant (Dağüstü, 2002; Knittel et al., 1991; Paterson and Everett, 1985; Shin et al., 2000); explant type (Ceriani et al., 1992; Dağüstü, 2002; Shin et al., 2000), and environmental factors (Fiore et al., 1997).

The lack of simple, effective, fast, genotype independent and uniform regeneration method is perceived as a major barrier to application of in vitro technologies into sunflower. If the regeneration from explant to mature plant development was successfully obtained with a suitable protocol, conservation of the genetic materials and/or gene transformation studies can be applied easily to this regeneration system.

Apical shoot meristem and apex culture have been used for over 40 years to obtain virus-free plants, mass production of desirable genotypes, production of clean material, regeneration of recalcitrant genotype, genetic transformation and/or in vitro conservation of germplasm. They are applied for true clonal propagation in both monocotyledonous and dicotyledonous species (Burrus et al., 1996; Gürel and Çaylak, 1991; Hewezi et al., 2003, Murashige, 1974). This paper describes the 
efficient in vitro regeneration and fertile plant development from apical shoot meristems into sunflower.

\section{MATERIALS AND METHODS}

Ten genotypes (T0910817-1, T0910950-2, T0910791-3, T0910182-2, T0910792-1, T0912285-1, T0911033-2, T0910791-1, T0910791-4, and T0910930-2) were obtained from TMT Ltd. Şti. Tekirdağ, Turkey. These genotypes were grown under field conditions at Uludağ University, Agricultural Research and Experiment Station in 2010.

The experiment was conducted in completely randomised design with 3 replications at Uludağ University, Agricultural Faculty, Field Crops Department, and Plant Tissue Culture Laboratory in 2011.

Mature seeds were separated from heads, rinsed for 30 min in running tap water, left $2 \mathrm{~min}$ in $70 \%$ alcohol, surface-sterilized in $30 \% \mathrm{NaOCl}+1$ drop Tween 80 for $40 \mathrm{~min}$. The seeds were soaked in sterile water for 1 hour, then dehusked and sterilized again in $3 \% \mathrm{NaOCl}+1$ drop Tween 80 for 5 min. Seeds were rinsed in sterile distilled water for 4-5 times and placed onto petri dishes ( 10 seeds/dish) with $1 / 2$ Murashige and Skoog (MS, 1962) basal salts supplemented with $1 \%$ sucrose, $0.5 \%$ agar at $\mathrm{pH} 5.7$. Seeds were incubated for germination at $26 \pm 2{ }^{\circ} \mathrm{C}$ in the light ( $16 \mathrm{~h} / 8 \mathrm{~h}$ day / night) for 4 days. Each petri dish contained 10 dehusked mature seeds and replicated 10 times.

The apical shoot meristems of sunflower genotypes were dissected from 4 dayold seedlings, transferred to $1 / 2$ MS medium described above and allowed shoot and root development. Each genotype was represented with 5 Petri dishes $(9 \mathrm{~cm})$ with 10 apical shoot meristems in each. At least 50 apical shoot meristems were placed into $1 / 2$ MS medium per genotype for experiment.

Within two weeks, the developing apical shoot meristems grew plantlets with strong roots $(2-6 \mathrm{~cm}$ and branching) and a stem $(3-5 \mathrm{~cm})$ with $6-8$ leaves. The 27 plantlets from each genotypes were washed agar debris and then placed in 31 by 51 $\mathrm{cm}$ plastic multipot trays containing 48 pots per tray with a sterile $1: 1: 2$ peatperlite-soil mixture (v:v). The trays were covered with plastic bags and incubated for a period of 7 days in the semi-controlled green houses at $25 \pm 2{ }^{\circ} \mathrm{C}$ in the day light ( $16 \mathrm{~h} / 8 \mathrm{~h}$ day/night), after which the plantlets taken from 7 genotypes were transferred to $320 \times 270 \mathrm{~mm}$ (16 lt) pots with regular soil and kept under the natural conditions. Each genotype had 3 pots within 6 plants and grew in the same green houses. The plantlets were irrigated with sterile water three times a week in order to maintain a high humidity environment and fertilized every 10 days. Plantlets had flowers eight weeks after sowing into pots and set seed. A number of agronomic traits (plant height, head diameter, number of leaves, stem diameter, number of branches) were determined for each of the individual plants in the pots. Data was 
HELIA, 34, Nr. 55, p.p. 55-62, (2011)

analyzed with Jump statistical programme in the completely randomized design with 3 replications, each replication consisted of one pot with 6 plants.

\section{RESULTS AND DISCUSSIONS}

The seven out of ten genotypes had good response to this tissue culture procedure. 3 genotypes were lost at the beginning of the culture. The causes of this loss might be genotypic and/or environmental factors. The selection of genotype and explant has a definite role in sunflower regeneration. Gürel and Kazan (1998) compared 10 different sunflower genotypes in terms of shoot formation from intact shoot-tip explants. They showed that the genotypic variation was clearly visible and shoot formation was significantly increased when hybrid genotypes used. Shoots developed rapidly and roots formed spontaneously after 2 weeks of culture as described by Freyssinet and Freyssinet (1988).

On the average, $67.33 \%$ of the apical shoot meristems plated develop plantlets with strong roots and stem with 6-8 leaves. The results are in accordance with the findings of Wilcox et al. (1988). The 27 well developed plantlets were transferred from petri dishes to viols for acclimatization after 2 weeks of cultivation. Almost all of the plantlets grew healthy in the viols in green house conditions (Table 1). The 18 of them were placed into pots ( 6 plantlets/pot) after 2 weeks in vials. They survived to flower and set seed after 8 weeks. The premature flowering did not occur in vitro. Mature plants exhibited normal phenotype and were fertile. When the variegated (unshaped and small) plantlets were transplanted to soil, they did not survive. The period from culturing to flowering and harvesting of mature seeds was almost 60-70 days, 110-120 days, respectively depending on the genotype. The seed production was between 1 and 123 seeds per plant with an average of 24 seeds (data are not shown).

Table 1: Estimation of the efficiency of the regeneration process

\begin{tabular}{lcccccc}
\hline Genotypes & $\begin{array}{c}\text { Sterilized } \\
\text { seed } \\
\text { number }\end{array}$ & $\begin{array}{c}\text { The apical shoot } \\
\text { meristems in cul- } \\
\text { ture }\end{array}$ & $\begin{array}{c}\text { Well devel- } \\
\text { oped plantlets }\end{array}$ & $\begin{array}{c}\text { Plantlets } \\
\text { transferred } \\
\text { to vials }\end{array}$ & $\begin{array}{c}\text { Plantlets } \\
\text { transferred } \\
\text { to pods }\end{array}$ & $\begin{array}{c}\text { Fertile } \\
\text { plants }\end{array}$ \\
\hline T0911033-2 & 100 & 60 & 58 & 27 & 18 & 18 \\
T0910817-1 & 100 & 60 & 56 & 27 & 18 & 18 \\
T0910950-2 & 100 & 60 & 58 & 27 & 18 & 18 \\
T0910791-3 & 100 & 60 & 57 & 27 & 18 & 18 \\
T0910182-2 & 100 & 70 & 58 & 27 & 18 & 18 \\
T0910792-1 & 100 & 70 & 59 & 27 & 18 & 18 \\
T0912285-1 & 100 & 70 & 58 & 27 & 18 & 18 \\
T0910791-1 & 100 & 50 & 0 & 0 & 0 & 0 \\
T0910791-4 & 100 & 50 & 0 & 0 & 0 & 0 \\
T0910930-2 & 100 & 50 & 0 & 0 & 0 & 0 \\
\hline
\end{tabular}


The analysis of variance showed significant differences between genotypes at the $5 \%$ probability level, for all traits except the number of branches (Table 2), revealing the presence of genetic diversity in the genotypes used.

Table 2: Analysis of variance for agronomic characters examined at in vitro regenerated plants from apical shoot meristems of sunflower (means square values)

\begin{tabular}{lcccccc}
\hline Variation Sources & DF & $\begin{array}{c}\text { Plant } \\
\text { height }\end{array}$ & $\begin{array}{c}\text { Head } \\
\text { diameter }\end{array}$ & $\begin{array}{c}\text { Number } \\
\text { of leaves }\end{array}$ & $\begin{array}{c}\text { Stem } \\
\text { diameter }\end{array}$ & $\begin{array}{c}\text { Number } \\
\text { of branches }\end{array}$ \\
\cline { 2 - 6 } & & $(\mathrm{cm})$ & $(\mathrm{cm})$ & $(\mathrm{no})$ & $(\mathrm{mm})$ & $(\mathrm{no})$ \\
\hline Genotypes & 6 & $1025.54^{*}$ & $1.44667^{*}$ & $28.6394^{\star}$ & $0.042063^{*}$ & $0.979908^{\text {ns }}$ \\
Error & 14 & 97.00 & 0.41762 & 3.7567 & 0.02000 & 0.886810 \\
Total & 20 & & & & & \\
\hline
\end{tabular}

${ }^{\star} \mathrm{p} \leq 0.05, \mathrm{~ns}$ : not significant

The mean values of all observations are summarized in Table 3. Plant height ranged from 43.33 to $102.67 \mathrm{~cm}$. The parent T0911033-2 had almost the highest agronomic performances but the lowest agronomic performances were obtained from parent T0912285-1. If the short type genotypes are not used, field grown plants are generally tall (most commonly 1.5 to $3 \mathrm{~m}$ ) and have large leaves (Hahne, 2002). Heads (1-3 cm diameter) contained mainly fertile seeds although sterile seeds were obtained.

Table 3: Mean of genotypes for agronomic characters examined at in vitro regenerated plants from apical shoot meristems of sunflower

\begin{tabular}{lccccc}
\hline \multirow{2}{*}{ Genotypes } & $\begin{array}{c}\text { Plant } \\
\text { height }\end{array}$ & $\begin{array}{c}\text { Head } \\
\text { diameter }\end{array}$ & $\begin{array}{c}\text { Number } \\
\text { of leaves }\end{array}$ & $\begin{array}{c}\text { Stem } \\
\text { diameter }\end{array}$ & $\begin{array}{c}\text { Number } \\
\text { of branches }\end{array}$ \\
\cline { 2 - 6 } & $(\mathrm{cm})$ & $(\mathrm{cm})$ & $(\mathrm{no})$ & $(\mathrm{mm})$ & $(\mathrm{no})$ \\
\hline T0911033-2 & $102.67 \mathrm{a}$ & $2.53 \mathrm{ab}$ & $14.37 \mathrm{a}$ & $0.57 \mathrm{a}$ & 2.00 \\
T0910817-1 & $60.03 \mathrm{~cd}$ & $2.43 \mathrm{ab}$ & $9.13 \mathrm{~b}$ & $0.20 \mathrm{~b}$ & 2.21 \\
T0910950-2 & $80.00 \mathrm{~b}$ & $3.37 \mathrm{a}$ & $8.70 \mathrm{bc}$ & $0.40 \mathrm{ab}$ & 1.38 \\
T0910791-3 & $64.37 \mathrm{bc}$ & $2.63 \mathrm{ab}$ & $6.27 \mathrm{bc}$ & $0.33 \mathrm{ab}$ & 2.54 \\
T0910182-2 & $65.80 \mathrm{bc}$ & $2.23 \mathrm{~b}$ & $7.90 \mathrm{bc}$ & $0.40 \mathrm{ab}$ & 2.90 \\
T0910792-1 & $63.80 \mathrm{bc}$ & $2.07 \mathrm{bc}$ & $5.73 \mathrm{c}$ & $0.30 \mathrm{~b}$ & 2.70 \\
T0912285-1 & $43.33 \mathrm{~d}$ & $1.07 \mathrm{c}$ & $5.33 \mathrm{c}$ & $0.27 \mathrm{~b}$ & 3.00 \\
\hline
\end{tabular}

All individual plants transferred to soil produced fertile and sterile seed, which provided normal sunflower plants. The seed production per head varied between 0123 seeds/head (data are not shown). All the agronomic characters obtained from in vitro regenerated plants decreased compared to field grown plants. The short vegetative phase of apical shoot meristem derived plants might be the cause of decreasing agronomic characters compared to field grown sunflower genotypes (Jambhulkar, 1995).

Fertile plant regeneration (Shin et al., 2000) has been also observed from embryo meristem and primordial leaf tissues. However, the plant heights of their in vitro regenerated genotypes were higher $(142-263 \mathrm{~cm})$ than genotypes used in this study $(43.33-102.67 \mathrm{~cm})$. 
Efficient and reliable regeneration system is necessary to apply the biotechnological methods for sunflower improvement. The culture of shoot apical meristems can be considered to be a reproductive method for examination of regeneration potential in sunflower. The majority of the genotypes tested produced mature plants.

Considerably high number of in vitro regenerated sunflower genotyopes in almost 3.5-4 months was obtained via apical shoot meristems culture method. This technique has been tested with 10 genotypes, only seven of which responded positively. However, 7 genotypes did not have genotypic effects in terms of regeneration potential. It suggests that this technique may be of general use for sunflower biotechnology studies. The technique described here allows the production of fertile plants from apical shoot meristem in 3.5-4 months.

A regeneration protocol described above is applicable to diverse genotypes and would be particularly useful for conservation and genetic transformation of sunflower plants. In fact, most genotypes tested produced mature plants with well developed seed. There are many advantages of this developed regeneration system. These are:

1) regeneration frequency is high enough to facilitate in vitro conservation and transformation of plants;

2) this system reduces the time for plant regeneration from explants;

3) somaclonal variation in the regenerated plants could be minimized.

\section{REFERENCES}

Burrus, M., Molinier, J., Himber, C., Hunold, R., Bronner, R., Rousselin, P., Hahne, G., 1996. Agrobacterium-mediated transformation of sunflower (Helianthus annuus L.). Molecular Breeding 2: 329-338.

Ceriani, M.F., Hopp, H.E., Hahne, G., Escandón, A.S., 1992. Cotyledons: An explant for rutine regeneration of sunflower plants. Plant Cell Physiol. 33(2): 157-164.

Dağüstü, N., 2002. Some factors affecting the plant regeneration in sunflower (Helianthus annuus L.). Biotechnology and Biotechnological Equipment 1(16): 18-23.

Encheva, J., Tsvetkova, F., Ivanov, P., 2004. Heritable tissue culture induced genetic variation in sunflower (Helianthus annuus L.) as a tool for crop improvement. Helia 27(41): 163172 .

Fiore, M.C., Trabace, T., Sunseri, A., 1997. High frequency of plant regeneration in sunflower from cotyledons via somatic embryogenesis. Plant Cell Reports 16: 295-298.

Freyssinet, M., Freyssinet, G., 1988. Fertile plant-regeneration from sunflower (Helianthus annuus L.) immature embryos. Plant Science 56(2): 177-181.

Greco, B., Tanzarella, O.A., Carrozzo, G. and Blanco, A., 1984. Callus induction and shoot regeneration in sunflower (Helianthus annuus L.). Plant Science 36: 73-77.

Gürel, A., Çaylak, Ö., 1991. Ayçiçeği (Helianthus annuus L.) in vitro teknikler. Ege Üniv. Zir. Fak. Derg. 28 (2-3): 227-250.

Gürel, E., Kazan, K., 1998. Development of an efficient plant regeneration system in sunflower (Helianthus annuus L.). Tr. J. of Botany 22: 381-387.

Hahne, G., 2002. Sunflower seed (Chapter 54). In: Khachatourians, G.G., McHughen, A., Scorza, R., Nip, W-K. and Hui, Y.H. (Eds.), Transgenic Plants and Crops. Pp. 813-830.

Hewezi, T., Jardinaud, F., Albert, G., Kallerhoff, J., 2003. A new approach for efficient regeneration of a recalcitrant genotype of sunflower (Helianthus annuus) by organogenesis induction on split embryogenic axes. Plant Cell, Tissue Organ Culture 73: 81-86. 
Jambhulkar, S.J., 1995. Rapid cycling through immature embryo culture in sunflower (Helianthus annuus L). Helia 18(22): 45-50.

Knittel, N., Escandón, A.S., Hahne, G., 1991. Plant regeneration at high frequency from mature sunflower cotyledons. Plant Science 73: 219-226.

Murashige, T., 1974. Plant propagation through tissue cultures. Annu. Rev. Plant Physiol. 25: 135-166.

Murashige, T. and Skoog, F., 1962. A revised medium for rapid growth and bioassays with tobacco tissue cultures. Physiol Plant. 15(3): 473-497.

Nurhidayah, T., Horn, R., Röcher, T., Friedt, W., 1996. High regeneration rates in anther culture of interspecific sunflower hybrids. Plant Cell Reports 16: 167-173.

Ozyigit, I.I., Gozukirmizi, N., Semiz, B.D., 2007. Genotype dependent callus induction and shoot regeneration in sunflower (Helianthus annuus L.). African Journal of Biotechnology 6(13): 1498-1502.

Paterson, K.E., 1984. Shoot tip culture of Helianthus annuus L. - flowering and development of adventitious and multiple shoots. American Journal of Botany 71: 925-931.

Paterson, K.E., Everett, N.P., 1985. Regeneration of Helianthus annuus inbred plants from callus. Plant Science 42: 125-132.

Power, C.J., 1987. Organogenesis from Helianthus annuus inbreed and hybrids from the cotyledons of zygotic embryos. Amer. J. Bot. 74(4): 497-503.

Sadhu, M.K., 1974. Effect of different auxins on growth and differentiation in callus tissue from sunflower stem pith. Indian. J. Exp. Bot. 12: 110-111.

Shin, D.H., Kim, J.S., Kim, I.J., Yang, J., Oh, S.K., Chung, G.C., Han, K.-H., 2000. A shoot regeneration protocol effective on diverse genotypes of sunflower (Helianthus annuus L.). In vitro Cell. Dev. Biol.-Plant 36: 273-278.

Wilcox McCann, A., Cooley, G., Dreser, J.V., 1988. A system for routine regeneration of sunflower (Helianthus annuus L.) from immature embryo-derived callus. Plant Cell Tissue and Organ Culture 14: 103-110. 
